\title{
Phage Display Analysis of Monoclonal Antibody Binding to Anthrax Toxin Lethal Factor
}

\author{
Jason M. Goldstein ${ }^{1, *}$, Joo Lee ${ }^{1}$, Xiaoling Tang ${ }^{1}$, Anne E. Boyer ${ }^{2}$, John R. Barr ${ }^{2}$, \\ Dennis A. Bagarozzi Jr. ${ }^{1}$ and Conrad P. Quinn ${ }^{3}$ \\ 1 Reagent and Diagnostic Services Branch, Division of Scientific Resources, \\ National Center for Emerging and Zoonotic Infectious Diseases, \\ Centers for Disease Control and Prevention, MS-A03, 1600 Clifton Road, Atlanta, GA 30333, USA; \\ JLee11@cdc.gov (J.L.); XTang@cdc.gov (X.T.); dbagarozzijr@cdc.gov (D.A.B.J.) \\ 2 Clinical Chemistry Branch, Division of Laboratory Services, National Center for Environmental Health, \\ Centers for Disease Control and Prevention, 4770 Buford Hwy, NE, Atlanta, GA 30341, USA; \\ ABoyer@cdc.gov (A.E.B.); JBarr@cdc.gov (J.R.B.) \\ 3 Meningitis and Vaccine Preventable Diseases Branch, Division of Bacterial Diseases, \\ National Center for Immunization and Respiratory Diseases, Centers for Disease Control and Prevention, \\ MS-D17, 1600 Clifton Road, Atlanta, GA 30333, USA; CQuinn@cdc.gov \\ * Correspondence: jgoldstein1@cdc.gov; Tel.: +1-404-639-2258
}

Academic Editor: Shihui Liu

Received: 27 April 2017; Accepted: 10 July 2017; Published: 13 July 2017

\begin{abstract}
AVR1674 and AVR1675 are monoclonal antibodies (mAbs) that bind with high specificity to anthrax toxin lethal factor (LF) and lethal toxin (LTx). These mAbs have been used as pivotal reagents to develop anthrax toxin detection tests using mass spectrometry. The mAbs were demonstrated to bind LF with good affinity $\left(\mathrm{K}_{\mathrm{D}} 10^{-7}-10^{-9} \mathrm{M}\right)$ and to enhance LF-mediated cleavage of synthetic peptide substrates in vitro. Sequence analysis indicated that the mAbs shared $100 \%$ amino acid identity in their complementarity determining regions (CDR). A phage display library based on a combinatorial library of random heptapeptides fused to the pIII coat protein of M13 phage was enriched and screened to identify peptide sequences with mAb binding properties. Selection and sequence analysis of 18 anti-LF-reactive phage clones identified a 7-residue (P1-P7) AVR1674/1675 consensus target binding sequence of $\mathrm{T}_{\mathrm{P} 1}-\mathrm{X}_{\mathrm{P} 2}-\mathrm{K} / \mathrm{R}_{\mathrm{P} 3}-\mathrm{D}_{\mathrm{P} 4}-\mathrm{D} / \mathrm{E}_{\mathrm{P} 5}-\mathrm{Z}_{\mathrm{P} 6}-\mathrm{X} / \mathrm{Z}_{\mathrm{P} 7}$ ( $\mathrm{X}=$ aromatic, $\mathrm{Z}=$ non-polar). The phage peptide sequence with highest affinity binding to AVR1674/1675 was identified as T-F-K-D-E-I-V. Synthetic oligopeptides were designed based on the phage sequences and interacted with $\mathrm{mAbs}$ with high affinity $\left(\mathrm{K}_{\mathrm{D}} \sim 10^{-9} \mathrm{M}\right)$. Single amino acid substitutions of $\mathrm{A}, \mathrm{H}$, or $\mathrm{Q}$ in the peptides identified positions $\mathrm{P} 1-\mathrm{P} 5$ as critical residues for $\mathrm{mAb}$-peptide interactions. CLUSTALW alignment of phage sequences with native LF implicated residues 644-650 (sequence T-H-Q-D-E-I-Y) as a putative linear epitope component located within a structural loop (L2) of LF Domain IV. The activation effects of these mAbs contribute to the analytic sensitivity of function-based LF detection assays.
\end{abstract}

Keywords: Bacillus anthracis; anthrax; monoclonal antibody; phage display; epitope; lethal factor; protective antigen; mass spectrometry

\section{Introduction}

Anthrax is caused by infection with Bacillus anthracis, a Gram-positive, spore-forming, bacterium of the Bacillus cereus group. B. anthracis is a Risk Group 2 and Category A Select Agent. Spores of B. anthracis are highly resistant to adverse environmental conditions [1]. B. anthracis produces two binary protein toxins comprising protective antigen (PA; $83 \mathrm{kDa}$ ) with either or both of edema factor 
(EF; $89 \mathrm{kDa}$ ) or lethal factor (LF; $90 \mathrm{kDa}$ ). EF is a calcium- and calmodulin-dependent adenylate cyclase. LF is a zinc-dependent endoprotease known to target the amino-terminus of the mitogen-activated protein kinase kinase (MAPKK) family of response regulators [2,3]. For anthrax toxin activity, full length PA (PA83) binds to specific cellular receptors and is proteolytically activated by the host cell into a $20 \mathrm{kDa}$ polypeptide of unknown function (PA20) and a self-assembling oligomer of up to eight copies of a $63 \mathrm{kDa}$ polypeptide (PA63). PA63 forms a ring-shaped oligomeric pre-pore that can simultaneously bind several molecules of LF and EF to form lethal toxin (LTx) and edema toxin (ETx), respectively [4,5]. Toxin complexes are internalized by receptor mediated endocytosis and the LF and EF are translocated to the host cell cytosol where their enzymatic activities promote anthrax pathogenesis [6].

We have previously reported the selection of murine anti-LF monoclonal antibodies AVR1674 and AVR1675 $(\mathrm{mAb})$ that do not neutralize LTx in vitro and the application of these mAbs for the development of LF and LTx detection technologies. The production of these mAbs, their LF-activation effect and their selection for use in LF detection assays as independent reagents have been reported previously [7-9]. The mAbs have been pivotal reagents in laboratory developed tests to evaluate biomarker development during $B$. anthracis infection in humans and animals, and for the assessment of immunotherapeutic interventions for clinical anthrax in humans [8-13]. In the present study, we demonstrated the ability of these mAbs to enhance LF cleavage of specific peptide substrates in vitro, verified their functional similarity and sequenced their complementarity determining regions to investigate their clonal relationship. To better define the potential binding sites in LF, a phage display combinatorial library of random heptapeptides fused to the PIII coat protein of M13 phage was enriched and screened to identify peptide mimetic sequences for high affinity $\mathrm{mAb}$ binding. Amino acid substitution analysis identified important residues in the phage peptide binding site interactions and protein sequence alignments implicated a putative linear binding region within the native anthrax toxin LF protein.

\section{Results}

\subsection{Comparative Analysis of AVR1674 and AVR1675 mAb Sequences}

Sequence analysis of the $\mathrm{F}_{(\mathrm{ab})}$ framework and hypervariable heavy chains were demonstrated for the clones (Figure 1). The CDR amino acid sequences of both anti-LF mAbs were demonstrated to be 100\% identical and submitted to GenBank (accession number KY985351).

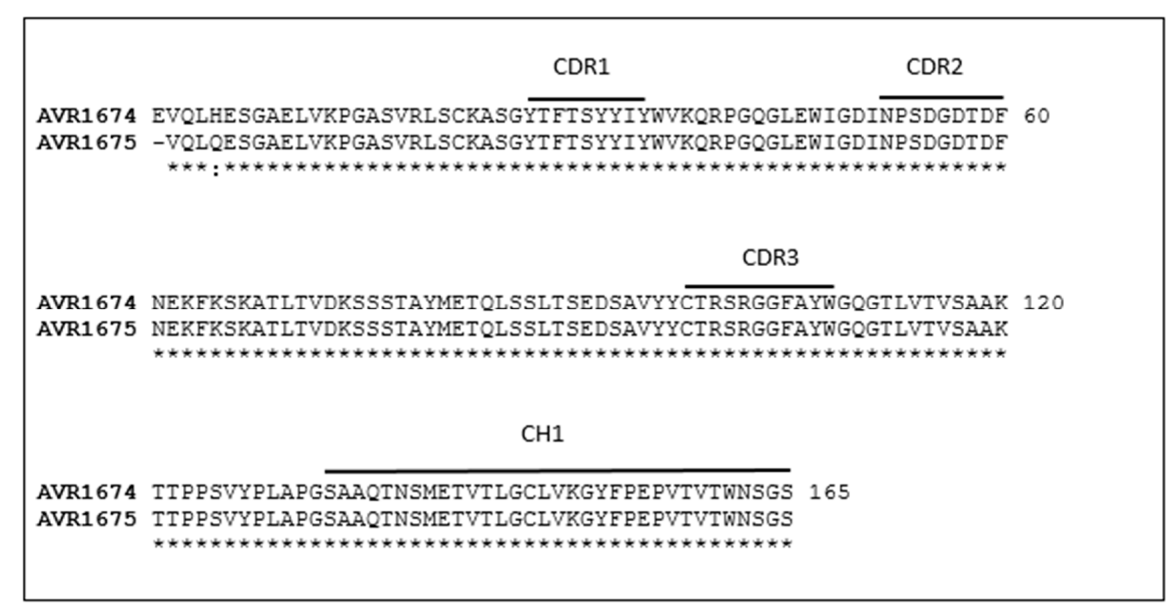

Figure 1. Sequence alignment of IgG heavy chains from AVR1674 and AVR1675. Anti-LF heavy chain $\mathrm{F}_{(\mathrm{ab})}$ and $\mathrm{CH} 1$ amino acid sequences for AVR1674 (LFG2:4B10) and AVR1675 (LFG2:3D10) were translated from the cDNA nucleotide sequences. Solid lines define CDRs 1-3 and CH1 regions. Identical residues are denoted with an asterisk and similar residues with a colon. Each clone was sequenced in duplicate in independent sequencing reactions. 


\subsection{Antibody-Enhanced Activity of rLF In Vitro}

The rLF activation profiles for both $\mathrm{mAb}$ clones were compared over a $20 \mathrm{~h}$ incubation period to measure the effect of excess $\mathrm{mAb}$ for differences in MAPKK-like synthetic peptide substrate cleavage (Figure 2) [7,8]. A concentration-dependent activity-enhancing effect of both anti-LF mAbs was observed increasing rapidly from baseline mAb:LF molar ratios of approximately 1.5:1 up to the highest ratios. The product accumulation of cleaved substrate reached a maximum at the highest measured mAb:LF molar ratio of 960:1. There was approximately a 9.5-10-fold observed increase in rLF activity relative to the absence of anti-LF $\mathrm{mAb}$. There was a slight increase in the non-anti-LF $\mathrm{mAb}$ AVR1046 (anti-PA IgG) at the highest ratios but it was non-specific and similar to that by the PG beads alone. The anti-LF mAb clones were still more than 4.25-fold higher than the non-anti-LF and PG alone at the 960:1 molar ratio and 5.6-fold higher at 192:1.

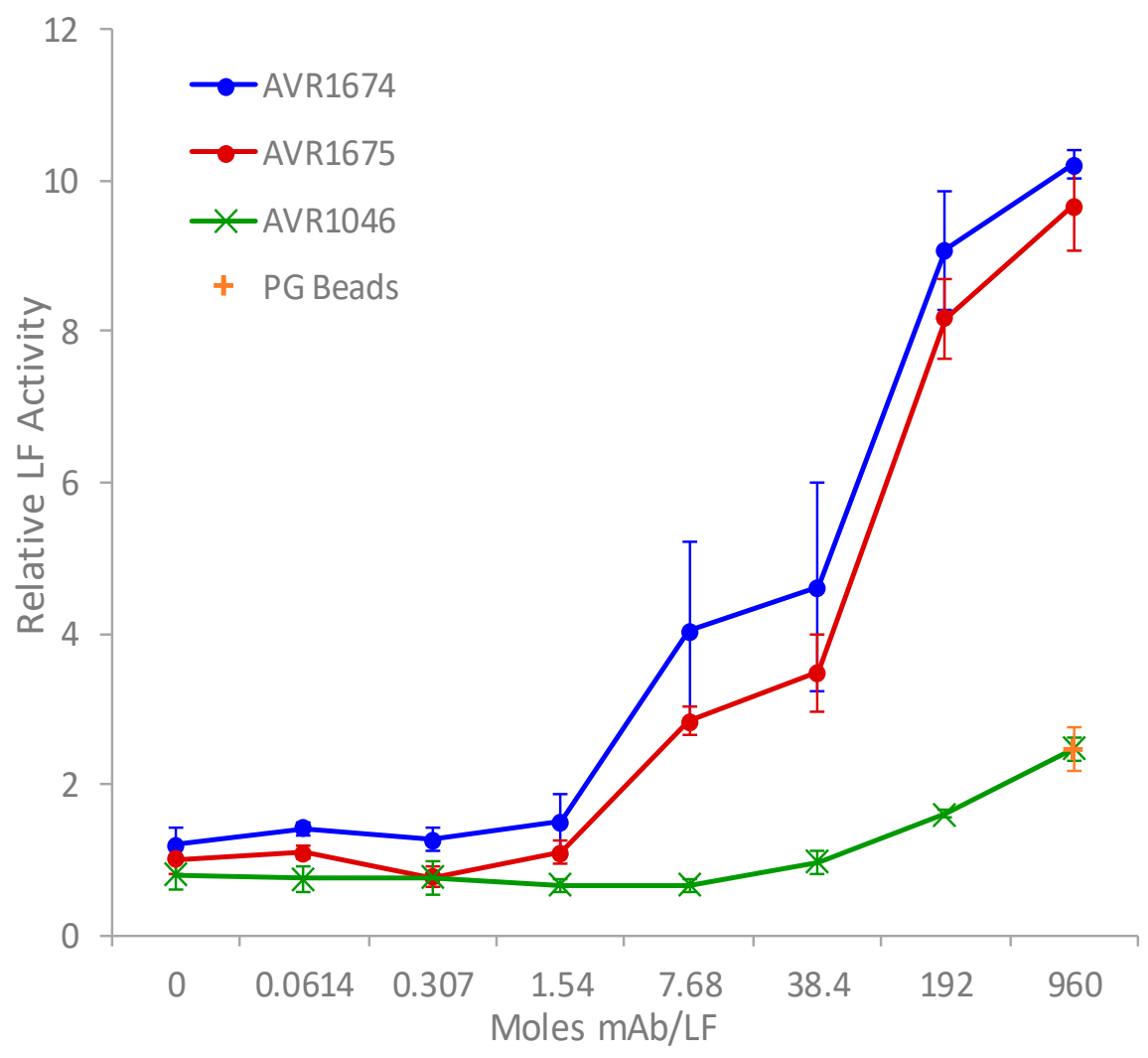

Figure 2. Antibody-enhanced activity of rLF in vitro. Anti-LF mAb clones, AVR1674 and AVR1675, and non-anti-LF mAb clone, AVR1046 (anti-PA IgG), were linked to protein G magnetic beads by FC interactions. $\mathrm{mAb}$ bead concentrates were serially diluted, then each level was mixed in triplicate with $10 \mathrm{ng}$ ( 0.11 picomoles) $\mathrm{rLF}$, allowed to bind, then reacted with synthetic peptide substrate for $20 \mathrm{~h}$. Concentrated protein G beads alone were also mixed with rLF and analyzed. Triplicates were averaged. Mean and standard deviations (error bars) were graphed vs. mAb/rLF molar ratio.

\subsection{Competitive Binding of AVR1674 and AVR1675 to rLF}

The binding profiles of AVR1674 and AVR1675 to biotinylated rLF were compared using label-free bio-layer interferometry (BLI) analyses (Figure 3). Biotinylated rLF was immobilized onto streptavidin (SA) coated biosensors (60-360 s; not shown) with typical rLF capture levels of 1.0-1.2 nm ( \pm SD 0.15) within a row of eight tips. Variance was expressed as the standard deviation of the mean (SD) and was within the instrument background readings. Equivalent concentrations of anti-LF $\mathrm{mAb}$ interacted and adsorbed to the rLF ligand between 420-700 s (Figure 3); $K_{\text {off }}$ was monitored until 1100 s. The AVR1674 
and AVR1675 curves were near identical in terms of kinetic values for response (R), association rate $\left(K_{\text {on }}\right)$, and $K_{\mathrm{D}}$ (Table 1$)$.

We confirmed the functional identify of AVR1674 and AVR1675 binding to rLF and analyzed additional anti-LF $m A$ sb representing different anti-LF binding characteristics and unique $\mathrm{R}$ levels. These additional mAbs were classified as high-, intermediate-, and low-level rLF-binding controls for comparison to AVR1674/1675 (Figure 3). Functional identity of AVR1674 and AVR1675 was confirmed by mutual competitive binding. Sensors with existing $\mathrm{mAb}$-rLF immune complex were incubated with $200 \mathrm{nM}$ of AVR1675 for association times of 1200-1800 s. Existing AVR1674 and AVR1675 complexes blocked subsequent binding to AVR1675 by $90 \%$, indicating high levels of binding competition for these mAbs. In contrast, binding of all the additional anti-LF mAbs was supported.

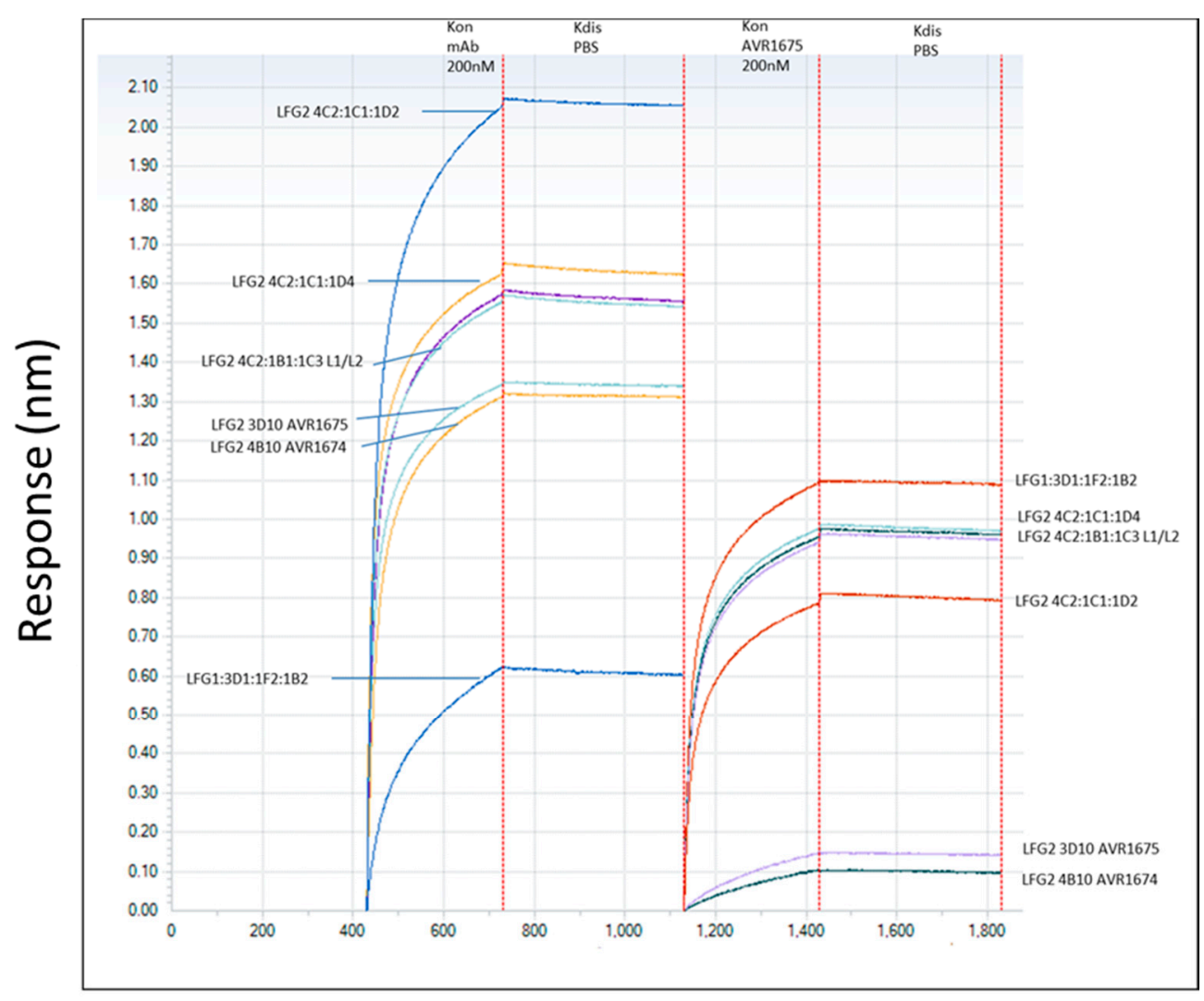

\section{Time (s)}

Figure 3. Anti-LF mAb binding and competition curves. Binding curves (left side of Figure; 420-1200 s) for multiple anti-LF mAbs to immobilized $\operatorname{rLF}(200 \mathrm{nM})$ were determined. Competition curves (right side of Figure; 1200-1800 s) were determined using AVR1675 binding to the existing LF-mAb complexes. Non-activating $m$ Abs which did not compete with AVR1674/1675, as well as unique epitopes to LF were selected. Based on response levels, they included high binder (LFG2 4C2:1C1:1D2), intermediate binders (LFG2 4C2:1C1:1D4; 4C2:1B1:1C3 L1/L2) and low binder (LFG1 3D1:1F2:1B2). Binding curves were further analyzed using the Octet Analysis module (ForteBio). Similar binding curve shapes of AVR1674/1675 and differing shapes among non-activating mAbs indicated unique kinetic profiles. Furthermore, significant association curves $(\mathrm{R} \geq 0.8)$ of AVR1675 onto existing non-activating mAb-LF complexes indicated limited competition whereas low-level association curves $(R \geq 0.2)$ indicated competition with self (AVR1675) or same epitope (AVR1674). Three independent assays were averaged and had a correlation coefficient of $r^{2} \geq 0.9$ for response levels. 
Table 1. Anti-LF mAb binding kinetic specifications. Binding affinities of anti-LF mAbs to rLF (200 nM) were measured using BLI label-free detection. Measurements of response binding curves and kinetic values indicate that performance of AVR1674 and AVR1675 were indistinguishable. The 5\% difference in $K_{D}$ is within the reported margin of error for BLI. $K_{D}$ and $K_{a s s o c}$ were calculated using the Octet Analysis module. Two independent assays were averaged and had a correlation coefficient $r^{2} \geq 0.88$ for AVR 1674/1675.

\begin{tabular}{ccccccc}
\hline $\begin{array}{c}\text { mAb Clone } \\
\text { ID }\end{array}$ & $\begin{array}{c}\text { Antibody } \\
\text { ID }\end{array}$ & $\begin{array}{c}\text { Concentration } \\
(\mathbf{n M})\end{array}$ & $\begin{array}{c}\text { Response } \\
\mathbf{( R )}\end{array}$ & $\mathbf{K}_{\mathbf{D}} \mathbf{( M )}$ & $\begin{array}{c}\mathbf{K}_{\text {assoc }} \\
\mathbf{( 1 / M s )}\end{array}$ & $\begin{array}{c}\text { Correlation } \\
\text { Coefficient }\left(\boldsymbol{r}^{\mathbf{2}}\right)\end{array}$ \\
\hline LFG2:4B10 & AVR1674 & 200 & 1.31 & $18.7 \times 10^{-9}$ & $1.37 \times 10^{5}$ & 0.913 \\
LFG2:3D10 & AVR1675 & 200 & 1.34 & $17.7 \times 10^{-9}$ & $1.68 \times 10^{5}$ & 0.875 \\
\hline
\end{tabular}

\subsection{Identification and Sequence Analysis of mAb-Binding Phage Peptide Sequences}

$\mathrm{F}_{(\mathrm{ab})}$ sequence data and competitive binding analyses by BLI confirmed the co-identity and functional properties of AVR1674 and AVR1675. A total of 100 phage clones was isolated from the heptapeptide library after three increased-stringency panning selections against mAb AVR1675 and evaluated for $\mathrm{mAb}$ binding by sandwich capture ELISA. From these, 18 clones were selected for sequencing based on reactivity levels in an rLF antigen ELISA (Figure 4).

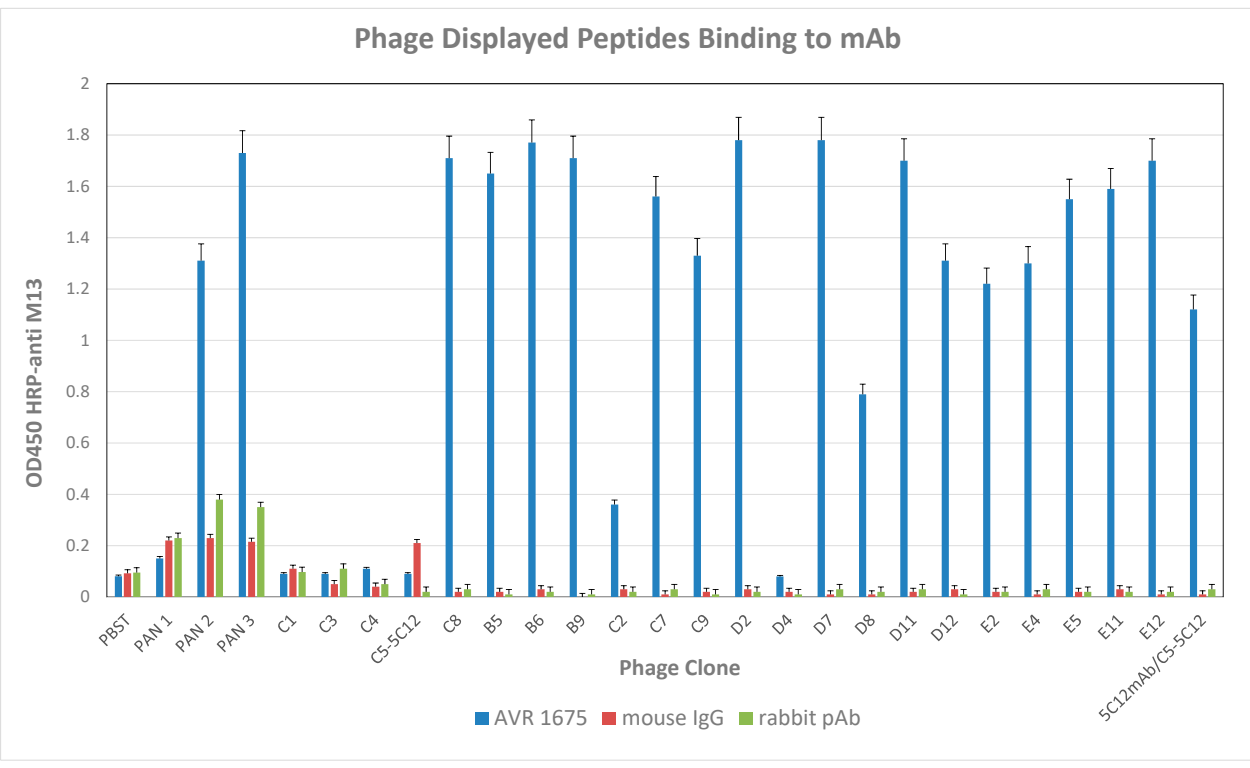

Figure 4. Reactivity of AVR1675 mAb with phage peptide. Coated AVR1675 was incubated with phage peptide clones and binding reported. An enrichment of peptide-specific phage in successive panning steps was observed. Mouse and rabbit polyclonal antibody $(\mathrm{pAb})$ confirmed lack of non-specific $\operatorname{IgG}$ binding. Phage $(\phi)$ C5-5C12 served as a positive control against target antibody mAb 5C12. Error bars represent one standard deviation above the mean from three independent assays.

Fifteen high-reactivity clones (OD $\geq 1.0)$, one intermediate reactivity clone $(0.5<\mathrm{OD}<1.0)$, and two low reactivity clones $(\mathrm{OD} \leq 0.5)$ were selected for sequence analysis (Table 2). Four unrelated phage clones $(\phi C 1, \phi C 3, \phi C 4$, and $\phi C 5)$ were included in the sequence analysis to evaluate the relationship between phage binding and peptide sequence. Competition ELISA was used to investigate specificity of the phage clones for the hypervariable region(s) of AVR1675 mAb. High ELISA reactive clone $\phi C 8$ was selected as representative of the high-binding phage clones (Table 2) and evaluated in a competition assay with rLF (Figure 5). Competition by rLF was able to reduce the interaction between phage and target $\mathrm{mAb}$ in a concentration dependent manner. These data suggest that the phage peptide was specific for the antibody binding domain. 
Table 2. Nomenclature, amino acid sequence, and anti-mAb reactivity of phage clones.

\begin{tabular}{|c|c|c|c|c|}
\hline $\begin{array}{l}\text { Panning Antibody } \\
\text { Identifier }\end{array}$ & $\begin{array}{l}\text { Panning Antibody } \\
\text { Reactivity }\end{array}$ & $\begin{array}{l}\text { Phage Sequence } \\
\text { Identifier }\end{array}$ & $\begin{array}{l}\text { Core Amino Acid } \\
\text { Sequence }\end{array}$ & $\begin{array}{c}\text { Phage ELISA Reactivity }(\text { High }=\text { OD }>1.0 \text {, } \\
\text { Intermediate }=\text { OD 0.5-1.0, Low }=\text { OD }<0.5)\end{array}$ \\
\hline \multirow{4}{*}{ AVR1046 } & \multirow{4}{*}{ Anti-PA } & Control- $\phi C 1$ & $\mathrm{NHHYSHL}$ & Negative control (OD 0.07) \\
\hline & & Control- $\phi C 3$ & $L P L T P L P$ & Negative control (OD 0.05) \\
\hline & & Control- $\phi C 4$ & $S P E A R H P$ & Negative control (OD 0.04) \\
\hline & & Control- $\phi C 5$ & Y A I LEDH & Negative control (OD 0.05) \\
\hline \multirow{20}{*}{ AVR1675 } & \multirow{20}{*}{ Anti-LF } & $\phi C 8$ & T F K D E I V & High (OD 1.71) \\
\hline & & $\phi \mathrm{D} 12$ & T F K D E I V & High (OD 1.31) \\
\hline & & $\phi \mathrm{E} 4$ & T F K D E I V & High (OD 1.30) \\
\hline & & $\phi E 11$ & T F K D E I V & High (OD 1.59) \\
\hline & & $\phi C 9$ & T F K D D I H & High (OD 1.33) \\
\hline & & \$B5 & $T Y K D D I R$ & High (OD 1.65) \\
\hline & & $\phi \mathrm{D} 2$ & $T Y K D D I R$ & High (OD 1.78) \\
\hline & & $\phi C 7$ & T F K D D L F & High (OD 1.56) \\
\hline & & $\phi \mathrm{D} 4$ & T F K D D G Y & Low (OD 0.08) \\
\hline & & $\phi \mathrm{B} 6$ & $T Y L D D L Y$ & High (OD 1.77) \\
\hline & & $\phi \mathrm{D} 11$ & $T Y L D D L Y$ & High (OD 1.70) \\
\hline & & $\phi \mathrm{E} 2$ & $T F L D D A P$ & High (OD 1.22) \\
\hline & & $\phi \mathrm{D} 8$ & $T W R D D I P$ & Intermediate (OD 0.79) \\
\hline & & $\phi \mathrm{E} 5$ & $T Y R D D P P$ & High (OD 1.55) \\
\hline & & $\phi C 2$ & $T \vee L D D \vee A$ & Low (OD 0.36) \\
\hline & & $\phi \mathrm{D} 7$ & $T \vee R D D Q I$ & High (OD 1.78) \\
\hline & & $\phi \mathrm{B} 9$ & TFR E P M & High (OD 1.71) \\
\hline & & $\phi \mathrm{E} 12$ & $T \vee R D E P L$ & High (OD 1.70) \\
\hline & & Consensus & $\mathrm{T} X \mathrm{~K} / \mathrm{R} D \mathrm{E} \mathrm{Zn}$ & $\mathrm{N} / \mathrm{A}$ \\
\hline & & LF(644-650) & 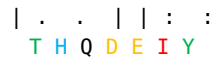 & N/A \\
\hline
\end{tabular}

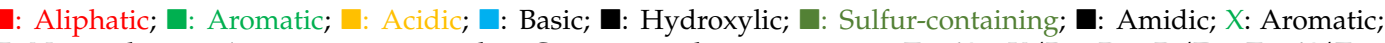
$\mathrm{Z}$ : Non-polar; n: Aromatic or non-polar; Consensus phage sequence: $\mathrm{T}_{\mathrm{P} 1}-\mathrm{X}_{\mathrm{P} 2}-\mathrm{K} / \mathrm{R}_{\mathrm{P} 3}-\mathrm{D}_{\mathrm{P} 4}-\mathrm{D} / \mathrm{E}_{\mathrm{P} 5}-\mathrm{Z}_{\mathrm{P} 6}-\mathrm{X} / \mathrm{Z}_{\mathrm{P} 7}$; Anti-PA: Murine monoclonal antibody against anthrax toxin protective antigen.

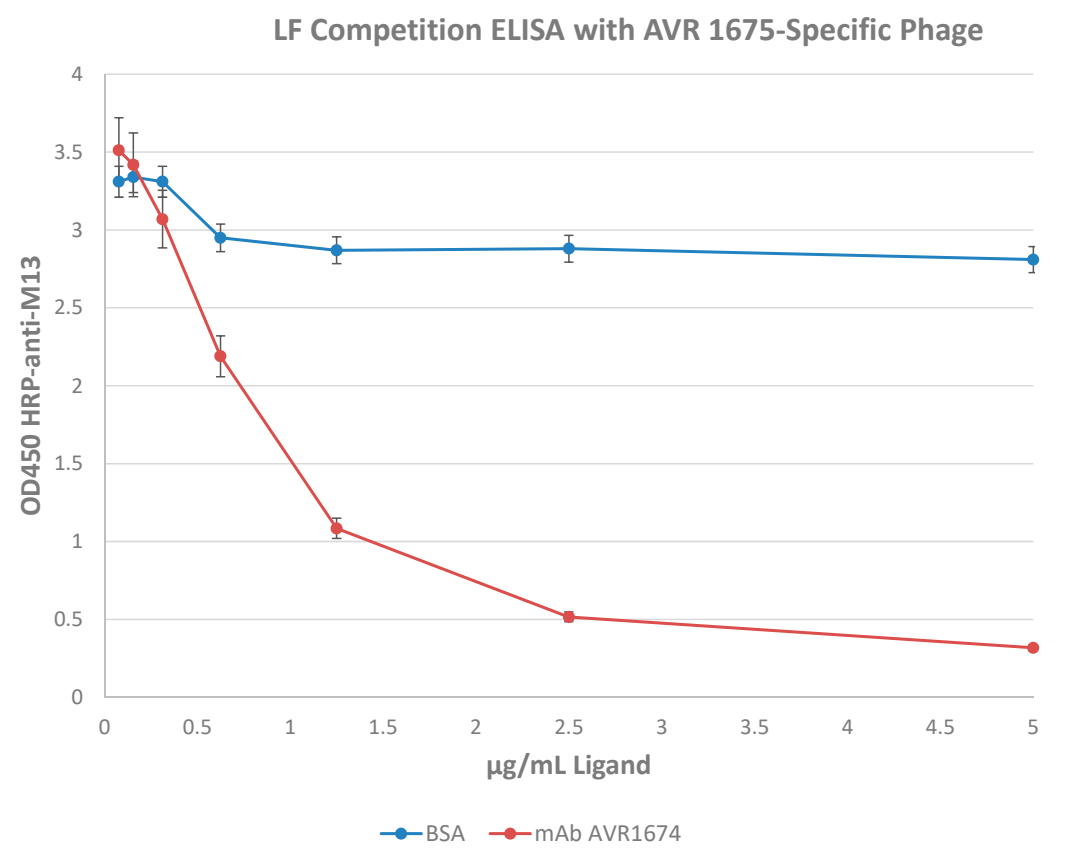

Figure 5. Competition ELISA with recombinant lethal factor. AVR1675 mAb (15 $\mu \mathrm{g})$ was coated and tested for binding to a mixture of pre-incubated phage AVR1675- $\Phi$ C8 with titrations of recombinant LF or BSA (negative control). The $\mathrm{IC}_{50}$ was approximately $1.0 \mathrm{ng} / \mu \mathrm{L} \mathrm{rLF}$ with phage at $1 \times 10^{10} \mathrm{pfu} / \mathrm{mL}$. Increasing concentrations of rLF were used to compete binding of phage $\Phi C 8$-displayed peptide binding to mAb AVR1675, indicating a specific interaction between peptide and mAb CDRs. BSA was used as a non-competing negative control. Error bars represent one standard deviation from the mean of three independent assays. 
Selected clones yielded unambiguous sequences that permitted read-through and translation of residues in the peptide insert and into the pIII-fusion protein of M13 phage. Translated amino acid sequences were annotated as NH2-P1-P2-P3-P4-P5-P6-P7-G-G-G-COOH and aligned by CLUSTAL-X. Four phage $(\phi \mathrm{C} 8, \phi \mathrm{D} 12, \phi \mathrm{E} 4$, and $\phi \mathrm{E} 11)$ with high anti-mAb ELISA reactivity had the same peptide sequence T-F-K-D-E-I-V in positions P1-P7 (Table 2). Two additional phage clones ( $\phi$ B5 and $\phi D 2)$ with high ELISA reactivity had the sequence T-Y-K-D-D-I-R. The remaining clones with high anti-mAb ELISA reactivity had identical or similar amino acids at conserved positions. Though exceptions were evident, a general trend in amino acid sequence of phage clones with high ELISA reactivity was evident. All peptides had the uncharged polar nucleophilic T at P1; P2 was occupied by aromatic (F, Y, W) or hydrophobic (V) residues; P3, basic (R or K) or hydrophobic (L); P4 and P5, acidic (D or E); and P6 small (V or A) or hydrophobic (I, L, P, or V). Greater residue variability was seen at $\mathrm{P7}$ but, in general, the amino acid at this position was aromatic or non-polar with a bulky side group (F, H, P, I or Y). CLUSTAL-W alignment of high reactive anti-mAb ELISA phage sequences indicated a seven-residue phage peptide consensus sequence of $T_{P 1}-X_{P 2}-K / R_{P 3}-D_{P 4}-D / E_{P 5}-Z_{P 6}-X / Z_{P 7}$ ( $\mathrm{X}=$ aromatic, $\mathrm{Z}=$ non-polar). Alignment of this consensus with the native protein LF primary sequence indicated a best match within the six-amino acid linear sequence T-H-Q-D-E-I-Y, corresponding to residues 644-650 of mature LF. Analysis indicated four identical and two similar positions by CLUSTAL-Omega and a score of $89 \%$ by T-COFFEE, which is considered to be a good match. The low ELISA binding of $\phi D 4$ may be due to the smaller $\mathrm{G}$ residue at $\mathrm{P} 6$, which is its only difference from the consensus. The intermediate ELISA reactivity of $\phi \mathrm{D} 8$ may be due to the larger size of $\mathrm{W}$ at P2.

\subsection{Analysis of Synthetic Oligopeptide Binding to $m A b$}

BLI data for biotinylated peptide binding to AVR1675 mAb are shown in Figure 6. Synthetic oligopeptides were designed based on P1-P6 of the phage peptides, including a C-terminal spacer arm similar to the fusion peptide on the phage pIII protein that reduces steric hindrance, and a synthetic C-terminal biotinylated $\mathrm{K}$ residue (G-G-G-S-K $\mathrm{bio}_{\mathrm{o}}$ ) (Table 3). A synthetic oligopeptide (T-F-K-D-E-I-G-G-G-S-K $\mathrm{bio}_{\mathrm{bio}}$ ) based on phage clone $\phi \mathrm{C} 8$ was used as the reference sequence for comparative binding analyses to the $\mathrm{mAb}$ and for comparison of oligopeptides with substitutions at positions P1 to P6. Three independent BLI assays for the reference peptide were averaged (Response $(\mathrm{R}=\mathrm{nm}$ shift)) with a standard deviation (SD) of $\leq 0.042$. The putative native LF binding region $\left(\mathrm{LF}_{644-652}\right)$ was represented by oligopeptide T-H-Q-D-E-I-Y-E-Q- $\mathrm{K}_{\mathrm{bio}}$ and an extended peptide comprising additional LF flanking sequences $\left(\mathrm{LF}_{637-664}\right)$ was represented by P-N-I-A-E-Q-Y-T-H-Q-D-E-I-Y-E-Q-V-H-S-K-G-L-Y-V-P-E-S-R-G-G-G-S-K

When the $\phi C 8$-derived oligopeptide was titrated below saturation conditions, a high-affinity interaction $\left(K_{D}=9.97 \times 10^{-9} \mathrm{M}\right)$ was calculated (Figure 6). Single residue substitutions at oligopeptide positions $\mathrm{P} 1, \mathrm{P} 3$, and $\mathrm{P} 4$ for $\mathrm{T}, \mathrm{K}$, and $\mathrm{D}$, respectively, resulted in large $(>89 \%)$ reductions in binding responses (R) to $\mathrm{mAb}$ AVR1675. Substitution at $\mathrm{P} 4$ also resulted in a substantial reduction in affinity, indicating the importance of an acidic residue at this position (Table 3). For P2 there was approximately a $22 \%$ reduction with an $\mathrm{A}$ substitution and $>50 \%$ reduction with a $\mathrm{Q}$ substitution. The substitution of $\mathrm{A}$ for $\mathrm{E}$ at $\mathrm{P} 5$ caused an $80 \%$ reduction in $\mathrm{R}$ indicating that an acidic residue was preferred at this position. The substitution of A for I at P6 was tolerated, with no observed reduction in $\mathrm{R}$. The native $\mathrm{LF}_{644-652^{-}}$ and $\mathrm{LF}_{637-664}$-derived oligopeptides bound at only $14 \%$ of the $\mathrm{R}$ measured with the $\phi \mathrm{C} 8$-derived reference oligopeptide. These data demonstrated that these native LF sequence derived peptides were not effective mimetics for $\mathrm{mAb}$ binding to the full length LF protein. The substitution of $\mathrm{H}$ for aromatic $\mathrm{F}$ at $\mathrm{P} 2$ caused a $52 \%$ reduction in binding, while a $\mathrm{Q}$ (uncharged, polar) for $\mathrm{K}$ (basic, polar) at $\mathrm{P} 3$ of the $\phi \mathrm{C} 8$-derived oligopeptide caused a 70\% reduction in binding. Both of these substitutions, which represented increased homology to native LF, had overall negative effects on $\mathrm{mAb}$ binding. The $\phi C 8$-derived synthetic oligopeptide exhibited seven-fold higher binding $(R=4.84 \mathrm{~nm})$ compared to the LF-sequence derived oligopeptides, which both had similar low-level binding $(R=0.70 \mathrm{~nm})$. 


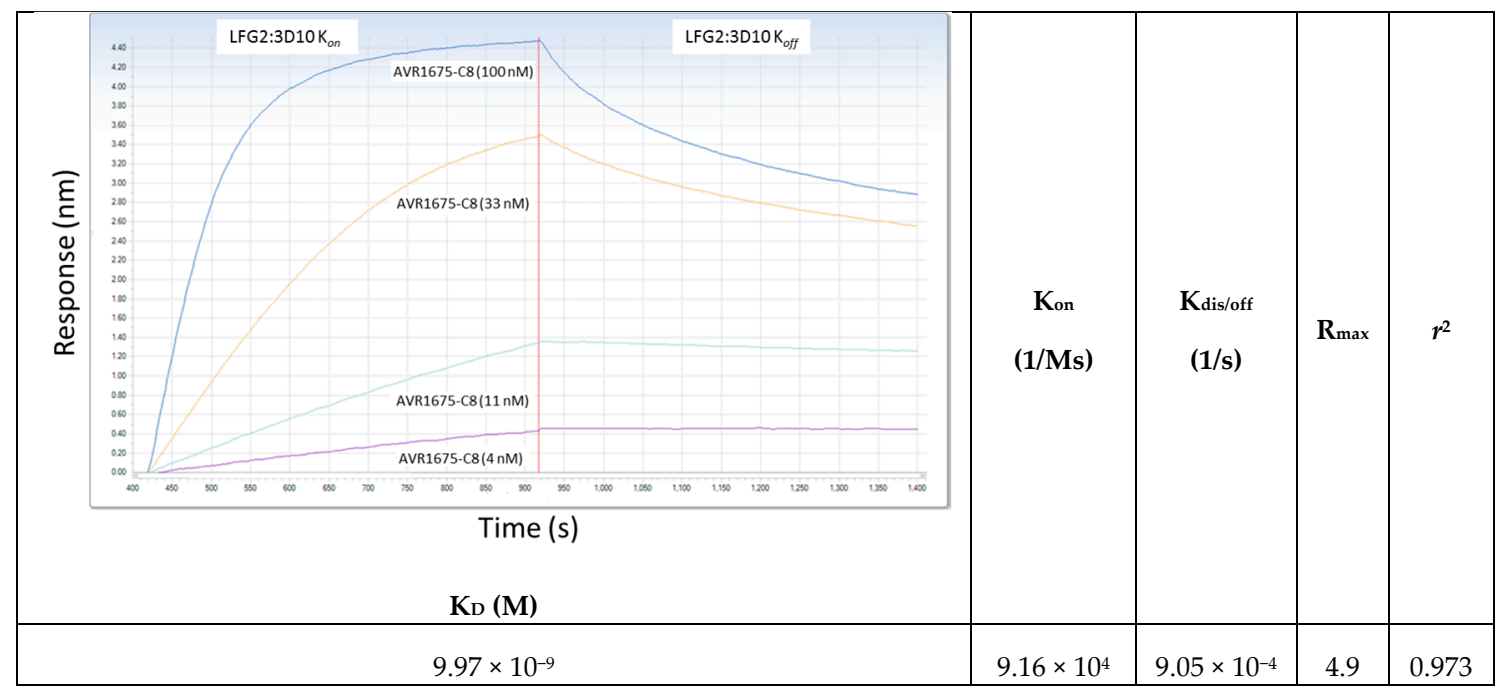

Figure 6. Kinetic determination of AVR1675- $\Phi C 8$ synthetic peptide binding to anti-LF mAb. The equilibrium affinity constant $\left(K_{D}=9.97 \times 10^{-9} \mathrm{M}\right)$ for AVR1675 binding to synthetic peptide AVR1675-ФC8 (T-F-K-D-E-I-G-G-G-S-K bio ) was calculated using BLI label-free detection and a four-point titration curve $(4,11,33$, and $100 \mathrm{nM})$. This approximates equilibrium affinity constants $\left(\mathrm{K}_{\mathrm{D}}=10 \times 10^{-9} \mathrm{M}\right)$ for anti-LF mAbs studied previously [14]. Mean data from three independent assays were reported (standard error $\leq 0.035$ ).

Table 3. Alanine (A) substitution at oligopeptide positions P1, P3, and P4 for T, K, and D, respectively, resulted in measurable reductions in binding to $\mathrm{mAb}$ AVR1675. Three independent assays on BLI were averaged (response $(R=\mathrm{nm}$ shift) $)$ with a standard deviation $\leq 0.042$. The $\phi C 8$ oligopeptide sequence T-F-K-D-E-I-G-G-G-S-K bio $_{\text {was }}$ used as the reference. Data indicated positions P1, P3, and particularly $\mathrm{P} 4$ as the most important in $\mathrm{mAb}$ binding. Oligopeptides based on native $\mathrm{LF}_{644-652}$ and $\mathrm{LF}_{637-664}$ bound at only $14 \% \mathrm{R}$, relative to the $\phi \mathrm{C} 8$ reference. These data demonstrated that these $\mathrm{LF}$ sequence peptides were not effective mimetics for $\mathrm{mAb}$ binding to the full length LF protein. *: Relative $\mathrm{K}_{\mathrm{D}}$ at $100 \mathrm{nM}$ of mAb AVR1675 was reported.

\begin{tabular}{|c|c|c|c|c|}
\hline Peptide Descriptor & Peptide Sequence Position & $\begin{array}{l}\text { Response } \\
\text { (nm) }\end{array}$ & $\begin{array}{c}\% \mathrm{R} \text { of } \\
\text { Consensus }\end{array}$ & $K_{D}(M) *$ \\
\hline & $1-2-3-4-5-6-7-8-9-\mathrm{S}-\mathrm{K}_{\mathrm{bio}}$ & & & \\
\hline$\phi C 8$-derived Reference Sequence & T-F-K-D-E-I-G-G-G-S-K & 4.8387 & 100 & $13.9 \times 10^{-9}$ \\
\hline P1 Substitution A & A-F-K-D-E-I-G-G-G-S-Kbio & 0.5352 & 11 & $35.1 \times 10^{-9}$ \\
\hline P2 Substitution A & $\overline{\mathrm{T}}-\underline{\mathrm{A}}-\mathrm{K}-\mathrm{D}-\mathrm{E}-\mathrm{I}-\mathrm{G}-\mathrm{G}-\mathrm{G}-\mathrm{S}-\mathrm{K}_{\mathrm{bio}}$ & 3.7854 & 78 & $31.5 \times 10^{-9}$ \\
\hline P3 Substitution A & T-F-A-D-E-I-G-G-G-S-Kbio & 0.4475 & 9 & $25.2 \times 10^{-9}$ \\
\hline P4 Substitution A & $T-F-\bar{K}-\underline{\mathbf{A}}-\mathrm{E}-\mathrm{I}-\mathrm{G}-\mathrm{G}-\mathrm{G}-\mathrm{S}-\mathrm{K}_{\mathrm{b} i \mathrm{o}}$ & 0.2612 & 5 & $>100 \times 10^{-9}$ \\
\hline P5 Substitution A & T-F-K-D-A-I-G-G-G-S-K $\mathrm{K}_{\mathrm{bio}}$ & 1.0132 & 21 & $24.5 \times 10^{-9}$ \\
\hline P6 Substitution A & T-F-K-D-E- $-\bar{A}-G-G-G-S-K_{b i o}$ & 5.2909 & 109 & $16.4 \times 10^{-9}$ \\
\hline P2 Substitution $\mathrm{H}$ & T- $-\underline{H}-\mathrm{K}-\mathrm{D}-\mathrm{E}-\overline{\mathrm{I}}-\mathrm{G}-\mathrm{G}-\mathrm{G}-\mathrm{S}-\mathrm{K}_{\mathrm{b} i \mathrm{o}}$ & 2.3704 & 48 & $60.1 \times 10^{-9}$ \\
\hline P3 Substitution Q & $T-\bar{F}-\mathbf{Q}-\mathrm{D}-\mathrm{E}-\mathrm{I}-\mathrm{G}-\mathrm{G}-\mathrm{G}-\mathrm{S}-\mathrm{K}_{\mathrm{bio}}$ & 1.3414 & 27 & $34.4 \times 10^{-9}$ \\
\hline Native LF core sequence & T-H-Q-D-E-I-Y-E-Q-Kbio $\quad\left(L_{644-652}\right)$ & 0.7024 & 14 & $>100 \times 10^{-9}$ \\
\hline Native LF extended sequence & $\begin{array}{c}\text { P-N-I-A-E-Q-Y-T-H-Q-D-E-I-Y-E-Q- } \\
\text { V-H-S-K-G-L-Y-V-P-E-S-R-G-G-G-S- } \\
\text { Kbio }_{\text {bio }}\left(L_{637-664}\right)\end{array}$ & 0.7024 & 14 & $>100 \times 10^{-9}$ \\
\hline
\end{tabular}

\section{Discussion}

AVR1674 and AVR1675 are two clones from the same NS1-B cell fusion. The mAbs were initially identified as independent reagents for use in a highly-sensitive and specific mass spectrometry-based assay for LF detection and quantification in clinical samples. Both mAbs have been used in detection assays in which LF is captured from samples using mAb bound to magnetic beads, exposed to a MAPKK-like oligopeptide substrate followed by hydrolysis, yielding two products of a specific mass 
detected by MALDI-TOF MS. Sequence analysis of the $F_{(a b)}$ framework and hypervariable heavy chains together with the comparative analysis of MAPKK substrate cleavage, demonstrated that the clones were indistinguishable by sequence and functional activity. Consequently, the mAbs were considered the same reagent (AVR1674/1675) for all subsequent analyses. These mAbs demonstrated $\mathrm{nM}$ affinity binding to rLF, did not neutralize rLF in vitro, and have the capacity for signal amplification by enhancing the accumulation of the enzyme-specific reaction products over time $[7,8]$. Elucidation of the $\mathrm{mAb}$ binding regions in $\mathrm{rLF}$ was, therefore, of particular interest.

A hepta-peptide combinatorial phage display library based on the pIII protein of the M13 phage was enriched for specific binding to mAb AVR1674/1675. Phage clones with high binding reactivity in ELISA had identical or similar amino acids at conserved positions. Phage peptide sequences indicated a consensus: $\mathrm{T}_{\mathrm{P} 1}-\mathrm{X}_{\mathrm{P} 2}-\mathrm{K} / \mathrm{R}_{\mathrm{P} 3}-\mathrm{D}_{\mathrm{P} 4}-\mathrm{D} / \mathrm{E}_{\mathrm{P} 5}-\mathrm{Z}_{\mathrm{P} 6}-\mathrm{X} / \mathrm{Z}_{\mathrm{P} 7}(\mathrm{X}=$ aromatic, $\mathrm{Z}=$ non-polar $)$. Specificity was confirmed by competitive binding of full-length rLF with phage clone $\phi C 8$ which was selected as the canonical phage sequence for comparative analyses.

Many monoclonal antibodies recognize linear epitopes on folded proteins as turns and extended turn-loops. Peptides that cross-react with such epitopes have been identified from peptide libraries [15] and $\mathrm{mAbs}$ that recognize linear epitopes and cross-react with phage peptides share structural features in common with the native epitope [16-18]. A key finding of this study was the identification of a putative linear target sequence for mAb AVR1674/1675 binding in anthrax toxin LF using the phage peptide sequence alignment. The alignment implicated the native LF binding target sequence as T-H-Q-D-E-I-Y located at residues 644-650. Competitive displacement of mAb binding to the phage AVR1675- $\phi$ C8 by rLF supported this interpretation. However, two synthetic oligopeptides based on the native LF sequence bound AVR1674/1675 with lower responses compared to synthetic oligopeptides derived from phage clone $\phi C 8$. These data indicate that, in contrast to the phage peptide, the conformations adopted by these two peptides are not representative of the full length protein.

Substitution of residues in the phage clone $\phi \mathrm{C} 8$ peptide with $\mathrm{H}$ and $\mathrm{Q}$ of the native LF sequence reduced relative binding as determined using BLI, indicating that the phage enrichment process had selected residues with greater affinity for mAb binding compared to rLF. Molecular modeling of the peptide residues (Figure 7) of the native LF residues was consistent with individual amino acids that have accessible bonding within the AVR1674/1675 paratope [19]. The data indicated that clone фC8 sequence (T-F-K-D-E-I-V) interacted with AVR1674/1675 in a structure that could mimic the native LF conformation better than the synthetic peptide derived from the LF epitope (T-H-Q-D-E-I-Y), implicating the substitution of $\mathrm{F}$ for $\mathrm{H}$ and $\mathrm{K}$ for $\mathrm{Q}$ at $\mathrm{P} 2$ and $\mathrm{P} 3$, respectively, as critical residues for enhanced binding.

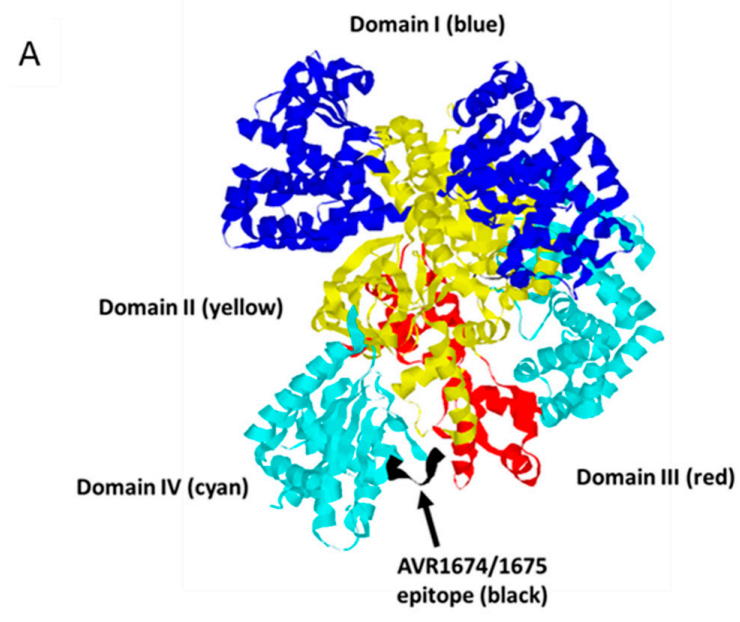

Figure 7. Cont. 


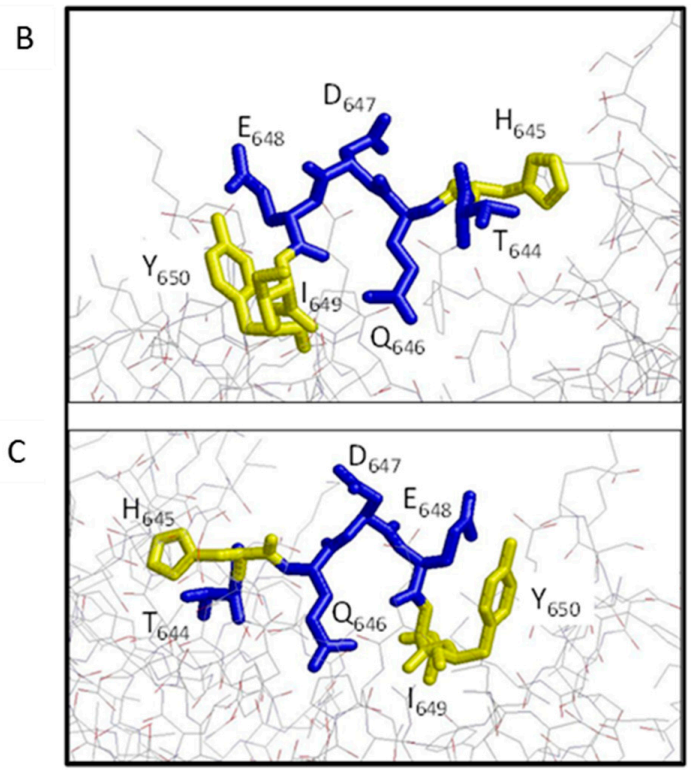

Figure 7. Molecular model of LF binding site for AVR1675. Rasmol analysis of lethal factor (Protein DataBank; PDB ID: 1J7N) at 2.6 angstroms. (A) Cartoon structure with Domains I (blue), II (yellow), III (red), and IV (cyan) with the putative epitope T-H-Q-D-E-I-Y (black) within the L2 loop of Domain IV. Inspection of the epitope and phage peptide data shows critical residues (colored blue) along with less restrictive residues (colored yellow). The model is directed behind the focal plane (B) and rotated $180^{\circ}$ on the horizontal axis $(\mathbf{C})$.

LF is considered to have evolved as an enzyme with high and unusual specificity [20]. The putative AVR1674/1675 binding region is located in a large ordered loop (L2) in Domain IV, which is inserted between two $\beta$-sheet strands, $4 \beta 2$ and $4 \beta 3$, and partially obscures the enzyme active site. Inspection of the LF solvent-exposed structure indicates that the most conserved residues of the consensus $\left(\mathrm{T}_{644}, \mathrm{D}_{647}\right.$ and $\mathrm{E}_{648}$ ) extend outward from the strands while the surrounding residues are oriented toward the interior of the molecule. These residues are, thus, coordinated in an exposed plane amenable to contact with CDRs of AVR1674/1675. This suggests that the phage peptide serves as a structural mimetic for residues in this loop that otherwise cannot be structured in a linear peptide. AVR1674/1675-enhanced synthetic substrate cleavage by rLF, suggesting that certain molecular interactions between $\mathrm{mAb}$ and rLF promote a more favorable catalytic conformation, such as the 'bioactive' state proposed by Maize and co-workers [21]. Importantly, L2 is not associated with substrate binding [20]. The mAb-associated enhancement of synthetic substrate cleavage by rLF in vitro may be indicative of the $\mathrm{L} 2$ region having both structural and functional roles in modulating LF enzymatic function. One implication of these data is that the L2 loop region may be a binding site for allosteric activator molecules in which the $\mathrm{mAb}$ mimics a positive effector activation in Domain IV that alters substrate access and hydrolysis at the catalytic site in Domain III. A structure-function assignment for L2 may, therefore, ensure optimal LF activation at the correct intracellular location. Mutational analysis of the full-length rLF protein is underway to confirm the AVR1674/1675 putative binding site in L2 and to evaluate further the role of AVR1674/1675 in enhancing enzymatic activity of rLF.

\section{Materials and Methods}

\subsection{Protein Reagents}

The phage display library was heptapeptide Ph.D.-7 (New England Biologics, Beverly, MA, USA) The Ph.D.-7 Phage Display Peptide Library is based on a combinatorial library of random heptapeptides fused to a minor coat protein (pIII) of M13 phage. The displayed peptide (7-mer) is expressed 
at the N-terminus of pIII followed by a short spacer (G-G-G-S) and the wild-type pIII sequence (https://www.neb.com/products/e8100-phd-7-phage-display-peptide-library-kit). Mouse anti-M13 phage IgG-HRP was from GE Healthcare (Piscataway, NJ, USA) and HRP-streptavidin was from Vector Labs (Burlingame, CA, USA). TMB (3,3',5,5'-tetramethylbenzidine) substrate and stop solutions were from KPL Inc. (Gaithersburg, MD, USA). Rabbit and human polyclonal (pAb) total IgG were from Thermo/Pierce Biotechnology (Rockford, IL, USA). Mouse total IgG and goat serum were from Jackson Immunoresearch, (West Grove, PA, USA). Recombinant anthrax toxin lethal factor (rLF) was from List Biologics (Campbell, CA, USA). rLF was biotinylated using NHS-PEG4-biotin at a 1:1 molar ratio for $30 \mathrm{~min}$ at $25^{\circ} \mathrm{C}$ (Thermo Fisher Scientific, Waltham, MA, USA). Synthetic oligopeptides were prepared using Fmoc synthesis with the incorporation of a C-terminal $\varepsilon$-amino group biotinylated lysine $\left(\mathrm{K}_{\mathrm{bio}}\right)$ to facilitate binding to SA biosensors (Biotechnology Core Facility Branch, Division of Scientific Resources, CDC, Atlanta, GA, USA). Streptavidin biosensors and kinetic buffer were from ForteBio (Menlo Park, CA, USA).

\subsection{Development of $m A b s$ AVR1674 and AVR1675}

Hybridomas producing LFG2 3F3:4B10 IgG1 kappa (AVR1674) and LFG2 3F3:3D10 IgG1 kappa (AVR1675) were generated with NS1-fused B-cells isolated from LF-immunized BALB/C mice. Clones were isolated after three rounds of limiting dilution cloning screening against rLF [7]. IgG1 was purified from hybridoma culture by HiTrap Protein G Sepharose ${ }^{\mathrm{TM}}$ affinity chromatography (GE Biosciences, Piscataway, NJ, USA) and concentrated to $5 \mathrm{mg} / \mathrm{mL}$ in $50 \mathrm{mM} \mathrm{HEPES} / 150 \mathrm{mM} \mathrm{NaCl}$ (pH 7.4). Protein preparations were analyzed for homogeneity by SDS-PAGE and Superdex ${ }^{\mathrm{TM}}-200$ size-exclusion chromatography (GE Biosciences, Piscataway, NJ, USA).

\subsection{Sequence Analysis of $m A b s$ AVR1674 and AVR1675}

Hybridoma cell line clones were propagated in Iscove's Modified Dulbecco's Media (IMDM) supplemented with 10\% fetal bovine serum (FBS) (Life Technologies, Rockford, IL, USA) in static culture at $37^{\circ} \mathrm{C}$ with $5 \% \mathrm{CO}_{2}$. Cells from each of LFG2 3F3:4B10 IgG1 kappa (AVR1674) and LFG2 3F3:3D10 IgG1 kappa (AVR1675) clones were harvested by centrifugation at $2000 \times g$ for $10 \mathrm{~min}$. Harvested cells were washed once in PBS ( $\mathrm{pH}$ 7.4) and total RNA extracted using Qiagen RNeasy Mini kit (Qiagen, Valencia, CA, USA) according to the manufacturer's instruction. Using the RNA as the template, mouse IgG heavy chain and light chain were amplified by Qiagen OneStep RT-PCR kit at the total reaction volume of $20 \mu \mathrm{L}$ (Qiagen, Valencia, CA, USA). Reverse transcription was performed at $50{ }^{\circ} \mathrm{C}$ for $30 \mathrm{~min}, 95^{\circ} \mathrm{C}$ for $15 \mathrm{~min}$, and 40 cycles of $94{ }^{\circ} \mathrm{C}$ for $1 \mathrm{~min}, 55^{\circ} \mathrm{C}$ for $1 \mathrm{~min}$, and $72{ }^{\circ} \mathrm{C}$ for $1 \mathrm{~min}$, followed by the final extension at $72{ }^{\circ} \mathrm{C}$ for $10 \mathrm{~min}$. A $5 \mu \mathrm{L}$ aliquot of each RT-PCR product was analyzed on $2 \%$ agarose gel electrophoresis and sequenced on an Applied Biosystems 3730XL sequencer (Thermo Fisher Scientific, Waltham, MA, USA). Sequencing primers were derived from established methods [22].

\subsection{Isotope-Dilution MALDI-TOF MS Quantification of $m A b$ Enhanced LF Activity}

Enhancement of anthrax toxin LF activity was evaluated using a mass spectrometry (MALDI-TOF MS) synthetic substrate cleavage assay as previously reported [7,8]. In the assay, LF cleaves the 'LF-5' synthetic peptide (S-K-A-R-R-K-K-V-Y-P-Y-P-X-E-N-F-P-P-S-T-A-R-P-T) between the P-Y residues (X represents norleucine). rLF protease activity releases an N-terminal (NT) and C-terminal (CT) peptide product for MALDI-TOF MS detection and quantification. For $\mathrm{mAb}$ analysis, AVR1674, AVR1675, and negative control anti-PA AVR1046 mAbs were bound to Dynabeads Protein $\mathrm{G}(\mathrm{PG})$ magnetic beads at $400 \mathrm{ng} / \mu \mathrm{L}$ beads according to the manufacturer's instructions. The mAb beads were washed twice in $\mathrm{dH}_{2} \mathrm{O}$ to remove storage buffer components, reconstituted in the starting volume in $\mathrm{dH}_{2} \mathrm{O}$, then serially diluted five-fold in $\mathrm{dH}_{2} \mathrm{O}$ from 400 to $0.0256 \mathrm{ng} / \mu \mathrm{L} \mathrm{mAb}$. Reactions with $\mathrm{mAb}$ beads and rLF were set up in triplicate containing $20 \mu \mathrm{L}$ of mAb at each concentration of bivalent $\mathrm{mAb}$ (106.67-0.0068 pmoles) and $10 \mu \mathrm{L} \mathrm{dH}_{2} \mathrm{O}$ alone. A triplicate reaction with non-diluted, 
washed PG beads was included as a concentrated PG control. Each dilution preparation was mixed with $10 \mu \mathrm{L} \mathrm{rLF}$ at $1 \mathrm{ng} / \mu \mathrm{L}$ (0.111 pmoles rLF) for molar ratios ranging from 960-0.061 mAb:rLF and no mAb (0:1). Dilution preparations were incubated for $30 \mathrm{~min}$ at ambient temperature. Reaction buffer was added $(30 \mu \mathrm{L}$ of $2.5 \times$ reaction buffer with peptide substrate for a final concentration of LF-mAb in 20 mM Hepes pH 7.3, 1 mM DTT, $20 \mu \mathrm{M} \mathrm{CaCl}_{2}, 10 \mathrm{mM} \mathrm{MgCl}_{2}, 20 \mu \mathrm{M} \mathrm{ZnCl}_{2}, 20 \mathrm{nmol}$ of LF substrate peptide) and the mixture was incubated at $37^{\circ} \mathrm{C}$. Aliquots of $3 \mu \mathrm{L}$ were sampled at 2 and $20 \mathrm{~h}$ of incubation and added to $27 \mu \mathrm{L}$ of $\alpha$-cyano-4-hydroxycinnamic acid (CHCA) at $5 \mathrm{mg} / \mathrm{mL}$ in $50 \%$ acetonitrile, $0.1 \%$ trifluoroacetic acid, and $1 \mathrm{mM}$ ammonium phosphate (CHCA matrix), with 1 pmol of isotopically-labeled NT- and CT-internal standard peptides (IS). For analysis, $1 \mu \mathrm{L}$ was spotted in quadruplicate onto a 384-spot stainless steel MALDI plate (AB Sciex, Framingham, MA, USA). Mass spectra were collected from 1000 to 3200 mass/charge $(\mathrm{m} / z)$, in MS positive ion reflectron mode on a AB Sciex 4800+ Proteomics Analyzer (Framingham, MA, USA). Areas of clustal isotopic peaks from the spectra were obtained and the ratio of the native C-terminal LF hydrolyzed peak area to the CT-IS peptide area gave the relative levels of LF cleaved peptide in each reaction and time point.

\subsection{Label-Free Binding and Competition Analyses}

$\mathrm{BLI}$ analyses of $\mathrm{mAb}-\mathrm{LF}$ and $\mathrm{mAb}$-peptide interactions were done using an Octet Red at $30{ }^{\circ} \mathrm{C}$ in kinetic buffer (KB) containing PBS pH 7.4 supplemented with $0.05 \%$ bovine serum albumin (BSA) and $0.02 \%$ Tween20 (Forte Bio, Menlo Park, CA, USA). rLF was biotinylated using NHS-PEG4-biotin. Streptavidin (SA) sensors were equilibrated for 10 min in KB in black 96-well microplates (VWR, Radnor, PA, USA) containing $200 \mu \mathrm{L}$ /well of KB only (controls) or KB with test sample and shaken at $1000 \mathrm{rpm}$ for $5 \mathrm{~min}$. SA-coated tips were saturated with $200 \mathrm{nM}$ biotinylated rLF. Purified mAb IgG (200 nM) was associated for $400 \mathrm{~s}$ to saturated LF-sensor followed by dissociation in buffer for 400 s. To measure residual binding (or competition for available LF binding sites), the same sensor with LF-IgG complex was associated for $200 \mathrm{~s}$ with $200 \mathrm{nM}$ AVR1675 and dissociated for $400 \mathrm{~s}$ in buffer. SA-coated tips were saturated with $25 \mu \mathrm{g} / \mathrm{mL}$ biotinylated synthetic oligopeptides at capture levels of $0.70 \pm 0.15 \mathrm{~nm}$. Purified mAb IgG was associated to the oligopeptide-saturated sensor, followed by dissociation in KB. A $200 \mathrm{nM}$ or titration of AVR1675 was associated up to $500 \mathrm{~s}$ and dissociated for $500 \mathrm{~s}$ in PBS buffer at $1000 \mathrm{rpm}$. Reference binding sensors were only peptide-corrected for baseline drift. Peptides were compared in the same experiment by coupling in triplicate. For mAb-peptide interaction, SA-coated tips were saturated with $25 \mu \mathrm{g} / \mathrm{mL}$ biotinylated synthetic peptides at capture levels of $0.70 \pm 0.15 \mathrm{~nm}$. Purified $\mathrm{mAb}$ was associated to peptide-saturated sensor followed by dissociation in KB. A $200 \mathrm{nM}$ or titration of AVR1675 was associated up to $500 \mathrm{~s}$ and dissociated for $500 \mathrm{~s}$ in PBS. Reference binding sensors containing only oligopeptide were corrected for baseline drift. Oligopeptides were compared in the same experiment by coupling in triplicate. Nanometer shift data were analyzed in Data Analysis 6.4 (ForteBio, Menlo Park, CA, USA). To estimate a direct binding affinity via the kinetic rate constants $\left(\mathrm{K}_{\mathrm{D}}=\mathrm{K}_{\mathrm{on}} / \mathrm{K}_{\mathrm{off}}\right.$, where $\mathrm{K}_{\mathrm{D}}$ = equilibrium dissociation rate constant, $\mathrm{k}_{\mathrm{on}}=$ association rate constant, and $\mathrm{k}_{\mathrm{off}}=$ dissociation rate constant) the buffer-subtracted octet data were fitted globally to a simple 1:1 Langmuir model.

\subsection{Binding Site Mapping and Competition with Phage Display Peptides}

The phage library $\left(2.0 \times 10^{11}\right.$ phage particles $\left./ \mathrm{mL}\right)$ was enriched for $\mathrm{mAb}$ binding clones using high binding 96-well microplates (Cova-link, Thermo Fisher, Waltham, MA, USA) coated overnight with target antibody AVR1675 in $100 \mathrm{mM}$ bicarbonate buffer (pH 9.1). In the first round, $100 \mathrm{pmol}$ of target $\mathrm{mAb}$ was adsorbed to the microplates and blocked with $50 \mathrm{mM}$ Tris- $\mathrm{HCl}, 150 \mathrm{mM} \mathrm{NaCl}, 0.5 \%$ Tween $20(v / v)$, pH 7.5 (TBST) supplemented with 5\% BSA for $1 \mathrm{~h}$ at $4{ }^{\circ} \mathrm{C}$ and washed three times with TBST. The target mAb was panned against phage in $150 \mu \mathrm{L}$ of TBST at ambient temperature on a plate shaker for $1 \mathrm{~h}$. Each sample was washed seven times with $150 \mu \mathrm{L}$ of TBST to reduce non-specific binding. Phage were eluted with $90 \mu \mathrm{L}$ of $0.1 \mathrm{M}$ Glycine- $\mathrm{HCl}(\mathrm{pH} 2.2), 5 \%$ BSA for $10 \mathrm{~min}$ at $25^{\circ} \mathrm{C}$ then neutralized with $15 \mu \mathrm{L}$ of $2 \mathrm{M}$ Tris, pH 9.1. Phage were amplified in $20 \mathrm{~mL}$ of E. coli ER2738 cells 
in early logarithmic phase in Luria-Bertani (LB) broth for $4-5 \mathrm{~h}$ at $37^{\circ} \mathrm{C}$ with $20 \mu \mathrm{g} / \mathrm{mL}$ tetracycline. E. coli ER2738 cells were cooled to $4{ }^{\circ} \mathrm{C}$ and centrifuged at $12,000 \times g$ for $15 \mathrm{~min}$ at $4{ }^{\circ} \mathrm{C}$. Phages were concentrated by precipitation with 0.25 volumes of $16.7 \%(w / v)$ polyethylene glycol $8000,2.5 \mathrm{M} \mathrm{NaCl}$ (PEG/NaCl). Stringency was introduced into successive selection steps by lowering the target $\mathrm{mAb}$ concentration used in panning from $100 \mathrm{pmol}$ to $10 \mathrm{pmol}$ in the final panning selection. The input phage concentration was maintained at $2 \times 10^{11} \mathrm{pfu} / \mathrm{mL}$ for each panning round using prior eluent. Phages were titered by spectroscopic methods [23]. For individual clone selection, E. coli ER2738 cultures were infected with phage from the third eluate between $1 \times 10^{8-10}$ phage particles $/ \mathrm{mL}$ and 10 single phage colonies (blue screen) were selected by inspection. Each clone was analyzed for binding to immobilized rLF by enzyme-linked immunosorbent assay (ELISA) and single-stranded DNA (ssDNA) extraction. For ELISA, antibodies were dissolved in carbonate buffer $(150 \mu \mathrm{L} /$ well $)$ in 96-well microtiter plate overnight at $4{ }^{\circ} \mathrm{C}$, washed with $50 \mathrm{mM}$ sodium phosphate, $150 \mathrm{mM} \mathrm{NaCl}$, $0.5 \%$ Tween 20 (PBST) and incubated in blocking buffer (PBS, $5 \%$ goat serum) for $1 \mathrm{~h}$ at $4{ }^{\circ} \mathrm{C}$. Phage particles were diluted in $150 \mu \mathrm{L} /$ well of PBST in triplicate and incubated for $1 \mathrm{~h}$ at $25^{\circ} \mathrm{C}$ with shaking. Plates were washed with PBST, HRP-labeled sheep anti-M13 IgG in PBST (1:5000) was added for $1 \mathrm{~h}$ at $25^{\circ} \mathrm{C}$, washed with PBS followed by $100 \mu \mathrm{L} /$ well TMB substrate. Stop solution $(100 \mu \mathrm{L} /$ well $)$ was added after $5 \mathrm{~min}$. Absorbance was measured on a Spectramax 380 plate reader at $450 \mathrm{~nm}$ (Molecular Devices, CA, USA). For the competition ELISA between phage peptide recombinant lethal factor (rLF) for AVR1675, $0-10 \mu \mathrm{g} / \mathrm{mL}$ of rLF was pre-incubated with phage clones for $10 \mathrm{~min}$ at room temperature. Phage and rLF were diluted in $150 \mu \mathrm{L} /$ well of PBST, in triplicate, and incubated for $1 \mathrm{~h}$ at room temperature on 96-well plate coated with $15 \mu \mathrm{g} / \mathrm{mL} \mathrm{mAb}$. The wells were washed five times with PBST. HRP-labeled sheep anti-M13 IgG in PBST (1:5000), $150 \mu \mathrm{L}$ per well, was added and incubated for $1 \mathrm{~h}$ at room temperature.

\subsection{Phage Sequencing and Analysis}

Viable phages were calculated by titrating amplified phages into competent E. coli ER2258 and counting X-gal-positive blue plaques in an agar overlay assay [24]. ssDNA from individual phage clones was purified by $\mathrm{NaI}$ and ethanol precipitation. The DNA from the selected clones was amplified by PCR using the Dye Terminator Cycle Sequencing Core Kit (PE Applied Biosystems, Foster City, CA, USA). The -28 gIII and -96 gIII primers were used for phage sequencing (New England Biolabs, Ipswich, MA, USA). cDNA sequences were analyzed on an ABI Prism 377 DNA sequencer (Perkin Elmer, Foster City, CA, USA). Sequence translations were compared by CLUSTAL-Omega (European Bioinformatics Institute (EMBL-EBI), Wellcome Genome Campus, CB10 1SD, United Kingdom) in FASTA format using Blosum (with a gap penalty $=10$, an extending $/$ separation gap penalty $=0.05$, and multiple sequence alignment [25], as well as by T-COFFEE [26]. RasMol V. 2.7.5 (Brookhaven Campus, Dowling College, Shirley, NY, USA) was used to analyze the crystal structure of LF [27]. Sequences have been deposited with GenBank under accession number: BankIt2011538 Seq1KY985351.

Acknowledgments: We thank the CDC Biotechnology Core Facility Branch, Division of Scientific Resources for the synthesis of peptides and sequencing of phage clones and $\mathrm{mAb} C D R s$ reported in this research.

Author Contributions: Conceived and designed the experiments: J.M.G., C.P.Q. Performed the experiments: J.M.G., J.L., X.T., A.E.B. Analyzed the data: J.M.G., D.A.B., A.E.B., C.P.Q. Contributed reagents $/ \mathrm{materials} /$ analysis tools: J.M.G., A.E.B., J.R.B., D.A.B., C.P.Q. Wrote the paper: J.M.G., C.P.Q.

Conflicts of Interest: The authors declare no conflicts of interest.

\section{References}

1. Mock, M.; Fouet, A. Anthrax. Annu. Rev. Microbiol. 2001, 55, 647-671. [CrossRef] [PubMed]

2. Brossier, F.; Mock, M. Toxins of Bacillus anthracis. Toxicon 2001, 39, 1747-1755. [CrossRef]

3. Klimpel, K.R.; Arora, N.; Leppla, S.H. Anthrax toxin lethal factor contains a zinc metalloprotease consensus sequence which is required for lethal toxin activity. Mol. Microbiol. 1994, 13, 1093-1100. [CrossRef] [PubMed] 
4. Katayama, H.; Janowiak, B.E.; Brzozowski, M.; Juryck, J.; Falke, S.; Gogol, E.P.; Collier, R.J.; Fisher, M.T. GroEL as a molecular scaffold for structural analysis of the anthrax toxin pore. Nat. Struct. Mol. Biol. 2008, 15, 754-760. [CrossRef] [PubMed]

5. Petosa, C.; Collier, R.J.; Klimpel, K.R.; Leppla, S.H.; Liddington, R.C. Crystal structure of the anthrax toxin protective antigen. Nature 1997, 385, 833-838. [CrossRef]

6. Collier, R.J. Mechanism of membrane translocation by anthrax toxin: Insertion and pore formation by protective antigen. J. Appl. Microbiol. 1999, 87, 283. [CrossRef]

7. Boyer, A.E.; Gallegos-Candela, M.; Lins, R.C.; Kuklenyik, Z.; Woolfitt, A.; Moura, H.; Kalb, S.; Quinn, C.P.; Barr, J.R. Quantitative mass spectrometry for bacterial protein toxins-A sensitive, specific, high-throughput tool for detection and diagnosis. Molecules 2011, 16, 2391-2413. [CrossRef]

8. Boyer, A.E.; Quinn, C.P.; Woolfitt, A.R.; Pirkle, J.L.; McWilliams, L.G.; Stamey, K.L.; Bagarozzi, D.A.; Hart J.C., Jr.; Barr, J.R. Detection and quantification of anthrax lethal factor in serum by mass spectrometry. Anal. Chem. 2007, 79, 8463-8470. [CrossRef]

9. Stoddard, R.A.; Quinn, C.P.; Schiffer, J.M.; Boyer, A.E.; Goldstein, J.; Bagarozzi, D.A.; Soroka, S.D.; Dauphin, L.A.; Hoffimaster, A.R. Detection of anthrax protective antigen (PA) using europium labeled anti-PA monoclonal antibody and time-resolved fluorescence. J. Immunol. Methods 2014, 408, 78-88. [CrossRef]

10. Boyer, A.E.; Quinn, C.P.; Beesley, C.A.; Gallegos-Candela, M.; Marston, C.K.; Cronin, L.X.; Lins, R.C.; Stoddard, R.A.; Li, H.; Schiffer, J.; et al. Lethal factor toxemia and anti-protective antigen antibody activity in naturally acquired cutaneous anthrax. J. Infect. Dis. 2011, 204, 1321-1327. [CrossRef] [PubMed]

11. Cui, X.; Nolen, L.D.; Sun, J.; Booth, M.; Donaldson, L.; Quinn, C.P.; Boyer, A.E.; Hendricks, K.; Shadomy, S.; Bothma, P.; et al. Analysis of Anthrax Immune Globulin Intravenous with Antimicrobial Treatment in Injection Drug Users, Scotland, 2009-2010. Emerg. Infect. Dis. 2017, 23, 56-65. [CrossRef] [PubMed]

12. Marston, C.K.; Ibrahim, H.; Lee, P.; Churchwell, G.; Gumke, M.; Stanek, D.; Gee, J.E.; Boyer, A.E.; Gallegos-Candela, M.; Barr, J.R.; et al. Anthrax Toxin-Expressing Bacillus cereus Isolated from an Anthrax-Like Eschar. PLoS ONE 2016, 11, e0156987. [CrossRef] [PubMed]

13. Sprenkle, M.D.; Griffith, J.; Marinelli, W.; Boyer, A.E.; Quinn, C.P.; Pesik, N.T.; Hoffmaster, A.; Keenan, J.; Juni, B.A.; Blaney, D.D. Lethal factor and anti-protective antigen IgG levels associated with inhalation anthrax, Minnesota, USA. Emerg. Infect. Dis. 2014, 20, 310-314. [CrossRef] [PubMed]

14. Lim, N.K.; Kim, J.H.; Oh, M.S.; Kee, S.; Kim, K.S.; Kang, H.J.; Inn, K.S. An anthrax lethal factor-neutralizing monoclonal antibody protects rats before and after challenge with anthrax toxin. Infect. Immun. 2005, 73, 6547-6551. [CrossRef] [PubMed]

15. Hoess, R.H.; Mack, A.J.; Walton, H.; Reilly, T.M. Identification of a structural epitope by using a peptide library displayed on filamentous bacteriophage. J. Immunol. (Baltim. Md. 1950) 1994, 153, 724-729.

16. Bonnycastle, L.L.; Mehroke, J.S.; Rashed, M.; Gong, X.; Scott, J.K. Probing the basis of antibody reactivity with a panel of constrained peptide libraries displayed by filamentous phage. J. Mol. Biol. 1996, 258, 747-762. [CrossRef] [PubMed]

17. Felici, F.; Luzzago, A.; Folgori, A.; Cortese, R. Mimicking of discontinuous epitopes by phage-displayed peptides, II. Selection of clones recognized by a protective monoclonal antibody against the Bordetella pertussis toxin from phage peptide libraries. Gene 1993, 128, 21-27. [CrossRef]

18. Schellekens, G.A.; Lasonder, E.; Feijlbrief, M.; Koedijl, D.G.; Drijfhout, J.W.; Scheffer, A.J.; Welling-Wester, S.; Welling, G.W. Identification of the core residues of the epitope of a monoclonal antibody raised against glycoprotein $\mathrm{D}$ of herpes simplex virus type 1 by screening of a random peptide library. Eur. J. Immunol. 1994, 24, 3188-3193. [CrossRef] [PubMed]

19. Gong, X.; Schopp, C.; Scott, J.K. The Performance of Epitope Libraries: Crystallographic Evidence for a Direct Correspondence between the Residues Selected and the Critical Residues for Binding. Protein Eng. 1993, 6, 106.

20. Pannifer, A.D.; Wong, T.Y.; Schwarzenbacher, R.; Renatus, M.; Petosa, C.; Bienkowska, J.; Lacy, D.B.; Collier, R.J.; Parks, S.; Leppla, S.H.; et al. Crystal structure of the anthrax lethal factor. Nature 2001, 414, 229-233. [CrossRef] [PubMed]

21. Maize, K.M.; Kurbanov, E.K.; De La Mora-Rey, T.; Geders, T.W.; Hwang, D.J.; Walters, M.A.; Johnson, R.L.; Amin, E.A.; Finzel, B.C. Anthrax toxin lethal factor domain 3 is highly mobile and responsive to ligand binding. Acta Crystallogr. Sect. D Biol. Crystallogr. 2014, 70, 2813-2822. [CrossRef] [PubMed] 
22. Smith, G.P. Filamentous phage assembly: Morphogenetically defective mutants that do not kill the host. Virology 1988, 167, 156-165. [CrossRef]

23. Smith, G.P.; Scott, J.K. Libraries of peptides and proteins displayed on filamentous phage. Methods Enzymol. 1993, 217, 228-257. [PubMed]

24. Barbas, C.F., 3rd; Burton, D.R.; Scott, J.K.; Silverman, G.J. (Eds.) Phage Display: A Laboratory Manual; Cold Spring Harbor Laboratory Press: New York, NY, USA, 2001.

25. Larkin, M.A.; Blackshields, G.; Brown, N.P.; Chenna, R.; McGettigan, P.A.; McWilliam, H.; Valentin, F.; Wallace, I.M.; Wilm, A.; Lopez, R. Clustal W and Clustal X version 2.0. Bioinformatics 2007, 23, 2947-2948. [CrossRef] [PubMed]

26. Notredame, C.; Higgins, D.G.; Heringa, J. T-Coffee: A novel method for fast and accurate multiple sequence alignment. J. Mol. Biol. 2000, 302, 205-217. [CrossRef] [PubMed]

27. Sayle, R.A.; Milner-White, E.J. RASMOL: Biomolecular graphics for all. Trends Biochem. Sci. 1995, $20,374$. [CrossRef]

(C) 2017 by the authors. Licensee MDPI, Basel, Switzerland. This article is an open access article distributed under the terms and conditions of the Creative Commons Attribution (CC BY) license (http:/ / creativecommons.org/licenses/by/4.0/). 